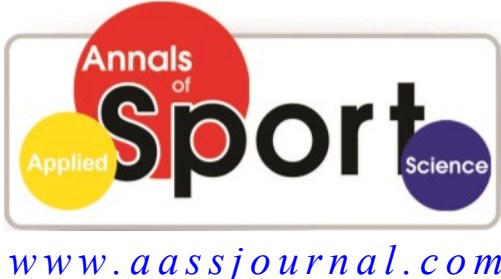

ISS N (Online): $2322-4479$

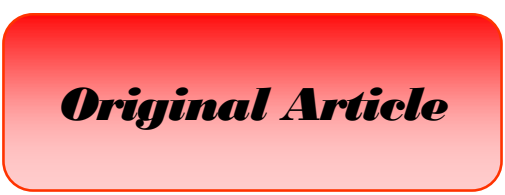

Received: 08/04/2014

Accepted: 25/11/2014

\title{
Effect of an Acute Incremental Exercise on Plasma Peptide YY, Neuropeptide $Y$ and IGF-1 Concentrations in Young Athletes
}

\section{${ }^{1}$ Hassan Faraji, ${ }^{2}$ Rahman Rahimi*, ${ }^{3}$ Saeed Dabagh Nikookheslat}

1. Department of Physical Education and Sport Science, Mariwan Branch, Islamic Azad University, Mariwan, Iran.

2. Department of Physical Education and Sport Science, University of Kurdistan, Sanandaj, Iran.

3. Faculty of Physical Education and Sport Science, Department of Exercise Physiology, University of Tabriz, Tabriz, Iran.

\begin{abstract}
This study aims to determine the effect of a single exhausting exercise on plasma PYY, NPY and IGF-1 in young athletes. Thirty-one young athletes (aged 19.52 \pm 2.75 years, body mass $79.24 \pm 16.13$ $\mathrm{kg}$, height $173 \pm 6.49 \mathrm{~cm}$, and body fat $16.37 \pm 5.92 \%$ ) volunteered to participate in this study. The participations, in randomized crossover manner, performed a single exercise bout on a cycle ergometer at 50 watts (W) for five-minute, and the power output was increased by $30 \mathrm{~W}$ every 3 minute until voluntary exhaustion. Venous blood samples were collected before (Pre), immediately after (Post) and $1 \mathrm{~h}$ after (1h Post) exercise to assess plasma PYY, NPY and IGF-1 concentrations. Plasma PYY ( $p=0.042)$ and IGF-1 $(p=0.001)$ significantly increased at Post exercise. Also, NPY was increased Post $(p=0.001)$ and for $1 \mathrm{~h}$ Post $(\mathrm{p}=0.021)$ exercise. The exhausting exercise increase plasma PYY concentration and this increase may relate to IGF-1 signals in young athletes. However, increased plasma NPY may not be related to stimulation food intake because it does not penetrate the blood-brain barrier.
\end{abstract}

Key Words: Appetite, Food Intake, Athletes, Anorexia.

Corresponding Author:

Hassan Faraji

E-mail: farajienator@gmail.com 


\section{INTRODUCTION}

Over-weight is not desirable and has implications for health and in the case of athletes affects performance. This later implication of over-weight makes necessary weight-control among athletes. Exercise is a strategy used to counteract overweight owing to create a negative energy balance by increasing energy expenditure and influencing appetite regulating hormones (1, 2).

Interestingly, recent studies have revealed inhibitory effects of exercise on the hunger associated with these hormones in healthy subjects (3), suggesting the intriguing possibility that exercise may promote a favorable appetite hormones profile yielding sustained appetite control and weight loss (2, 4). Therefore, it's suggested that exercise has an impact not only on energy expenditure but also on variations in appetite and postexercise energy intake, leading to negative energy balance (5).

Previous studies have reported that intense (but not necessarily moderate or light) exercise may induce a transient suppression of hunger that has been reported in both humans $(2,6)$ and experimental animals (7). This temporary repression of appetite has been termed 'exercise-induced anorexia' and it leads to a short-term negative energy balance (2). The specific mechanisms behind regulation of exerciseassociated changes in appetite are still under investigation. An important group of the intricate factors for appetite control involved in the brain-gut axis of eating behavior are ghrelin, cholecystokinin, pancreatic polypeptide, peptide YY (PYY), neuropeptide Y (NPY) and glucagon-like peptide-1. Some of these hormones suppress eating behavior, while others stimulate it. Recently, most attention has focused on PYY since this hormone is known to have strong appetite-suppressing effects (8). The peptide $\mathrm{YY}$ is a 36 amino acid polypeptide which is secreted predominantly from Lcells of the distal gastrointestinal tract. PYY have two main circulating form $\mathrm{PYY}_{1-36}$ and $\mathrm{PYY}_{3-36}$ (8). $\mathrm{PYY}_{3-36}$ is the major circulatory form of the hormone in the fed and fasted state (9). PYY bind with high affinity to all $\mathrm{Y}$ receptors, $\mathrm{PYY}_{3-36}$ shows high affinity for $\mathrm{Y}_{2}$ and some affinity for $\mathrm{Y}_{1}$ and $\mathrm{Y}_{5}$ receptors. It seems that $\mathrm{PYY}_{3-36}$ have peripheral action on appetite which may be mediated by the arcuate $\mathrm{Y}_{2}$ receptor resulting inhibition of NPY neurons and also central actions which is mediated by both $\mathrm{Y}_{1}$ and $\mathrm{Y}_{5}$ receptors results in stimulating food intake (8). Circulating PYY levels are influenced by food intake, type of food (9), gastric acid, cholecystokinin (CCK) and luminal bile salts, insulin like growth factor1 (IGF-1), and bombesin (9). In addition, NPY is a 36 amino acid neuropeptide which is one of the most potent orexigenic agents known $(9,10)$. NPY acts to stimulate feeding predominantly through activation of $\mathrm{Y}_{1}$ and $\mathrm{Y}_{5}$ receptors in the hypothalamus. Circulating NPY derive from the peripheral sympatho-adrenomedullary nervous system, platelets, lymphocytes, endothelial cells and smooth muscle (10). It seems that circulating NPY does not penetrate the blood-brain barrier (11). Therefore, NPY is produced and secreted from cell bodies of the arcuate nucleus in the hypothalamus into the paraventricular nucleus resulting increased appetite and food intake, suppressed activity of the sympathetic nervous system, decreased energy expenditure and increased activity of the parasympathetic nervous system (12).

Previous training studies have examined changes in fasting hormone responses before and after an exercise training intervention (13), but there are limited and controversial data regarding impact of acute exercise on plasma PYY $(4,14,15)$, with studies have reported the absence of an effect on PYY post-exercise $(15,16)$, and an increase in 
plasma PYY concentration (14, 17, 18). Regarding plasma NPY response to acute exercise, there are only three studies with reporting significant increase in plasma NPY after $45 \mathrm{~min}$ cycle ergometer (19) or significant decrease in plasma NPY after short-term treadmill exercise in obese rats (20) and incremental cycle ergometer test to exhaustion in athletes (21). Therefore, the aim of the present study was to investigate the effects of a single exhausting exercise bout on plasma PYY, NPY and IGF-1 (because PYY concentrations are influenced by IGF-1 signal) in young athletes.

\section{MATERIALS AND METHODS}

Participants. Thirty-one young men athletes were recruited to participate in this study (Table 1). All subjects had at least 6 years of experience in wrestling and were among the top 10 in national championships. The study was limited to males to reduce variation in hormonal response to the exercise. Subjects were fully informed of the study details and give their written consent prior to participation. The Institutional Review Board of the University approved the research protocol. All subjects had at least 4years experience in wrestling. Exclusion criteria were history of gastrointestinal, endocrine, cardiovascular or psychological disease, and consuming any supplementation, alcohol and tobacco products.

Table 1. Participants' Characteristics (M \pm SD)

\begin{tabular}{cccc}
\hline $\begin{array}{c}\text { Age } \\
\text { (year) }\end{array}$ & $\begin{array}{c}\text { Height } \\
(\mathrm{cm})\end{array}$ & $\begin{array}{c}\text { Weight } \\
(\mathrm{kg})\end{array}$ & $\begin{array}{c}\text { BF } \\
(\%)\end{array}$ \\
\hline $19.52 \pm$ & $173 \pm$ & $79.24 \pm$ & $16.37 \pm$ \\
2.75 & 6.49 & 16.13 & 5.92 \\
\hline
\end{tabular}

Protocol. Subjects undertook a randomized crossover design with an interval of 7 days between two study tests. To avoid diurnal rhythm effects, testing sessions began on the same time of the day.
Subjects came to the laboratory at $0800 \mathrm{~h}$ and, a standard breakfast (biscuits, yogurt, and jelly: $560 \mathrm{kcal}, 16.5 \%$ protein, $19.3 \%$ fat, and $64.2 \%$ carbohydrates) was then served at $0830 \mathrm{~h}$ and participants remained seated quietly. At $1030 \mathrm{~h}$, a venous blood sample $(6 \mathrm{ml})$ pre-exercise (pre) was taken then the subject exercised on the cycle ergometer. Then blood samples were collected immediately after (post), and $1 \mathrm{~h}$ after ( $1 \mathrm{~h}$ post) exhaustive exercise into tubes containing heparin. Each subjects performed the incremental exercise test to exhaustion began at 50 watts (W) for fiveminute, and the power output was increased by $30 \mathrm{~W}$ every 3 minute until voluntary exhaustion or the subject could no longer maintain a pedal cadence of $60 \mathrm{rpm}$ despite strong verbal encouragement. After the end of the exercise (post), and $1 \mathrm{~h}$ after ( $1 \mathrm{~h}$ post) blood samples were collected into tubes containing heparin. Subjects were instructed to refrain from exercise $72 \mathrm{~h}$ prior experimental session. All participants were instructed to follow their habitual diet throughout the study period and to fill out a food recall form for 3 days before the testing session (Table 2). The food recall forms were analyzed using the Nutritionist IV software (Diet analysis model 3.5.2, the Hearst Corporation, San Bruno, CA 94066) to determine total calories intake, carbohydrates, proteins and lipids.

Table 2. Dietary Intake Assessed during 3 Days prior to Exercise Session

\begin{tabular}{l|c}
\hline \multicolumn{1}{c|}{ Dietary intake } & Mean \pm SD \\
\hline Energy intake (kcal) & $2695.8 \pm 63.99$ \\
\hline Protein $(\mathrm{g})$ & $87.95 \pm 23.54$ \\
\hline Carbohydrate $(\mathrm{g})$ & $303.40 \pm 100.64$ \\
\hline Fat $(\mathrm{g})$ & $130.52 \pm 35.98$ \\
\hline
\end{tabular}

Blood Sampling and Hormonal Measurement. The taken blood samples were centrifuged at $1500 \times \mathrm{g}$ for $15 \mathrm{~min}$ then plasma was stored at $-20{ }^{\circ} \mathrm{C}$ until analysis. Plasma total PYY was analyzed in a single

Faraji, H., Rahimi, R., Dabagh, S., Nikookheslat. (2014). Ann Appl Sport Sci, 2(3): 23-32. 
run and in duplicate using Enzyme-Linked immunosorbent Assay Kit (Cat. No: E91067Hu, USCN Life Science Inc), IGF-1 and NPY was measured using EnzymeLinked immunosorbent Assay Kit (Boldon, Tyne \& Wear, United Kingdom) according to the manufacturer's protocol. To eliminate inter-assay variance, all samples for a particular assay thawed once and analyzed in the same assay run in duplicate. The coefficients of variations $(\mathrm{CV})$ were $7.1 \%$ for PYY, 6.9\% for IGF-1 and 7.3\% for NPY. The changes of plasma volume were calculated based on hemoglobin and hematocrit estimation. Results were adjusted in order to prevent pre-analytic error in the hormonal values (22).

Statistical Analysis. Descriptive statistics including means, standard deviations, and ranges were calculated for all measures. A two-way ANOVA was used to analyze the dependent measures of PYY and NPY with repeated-measures design. Bonferroni's post hoc test was used to determine significant findings over time, with significance accepted at $\mathrm{p}<.05$. The Student's paired t-test was used to determine the difference in IGF-1 concentration. All statistical analyses were performed using Statistical Package for Social Sciences (SPSS, Version 19.0) software.

\section{RESULTS}

There was a significant increase in adjusted plasma PYY concentration at postexercise in experimental group (Figure 1). The NPY concentration increased afterwards and $1 \mathrm{~h}$ post-exercise in experimental group (Figure 2). Also, IGF-1 concentration was significantly increased at post exercise in experimental group (Figure 3).

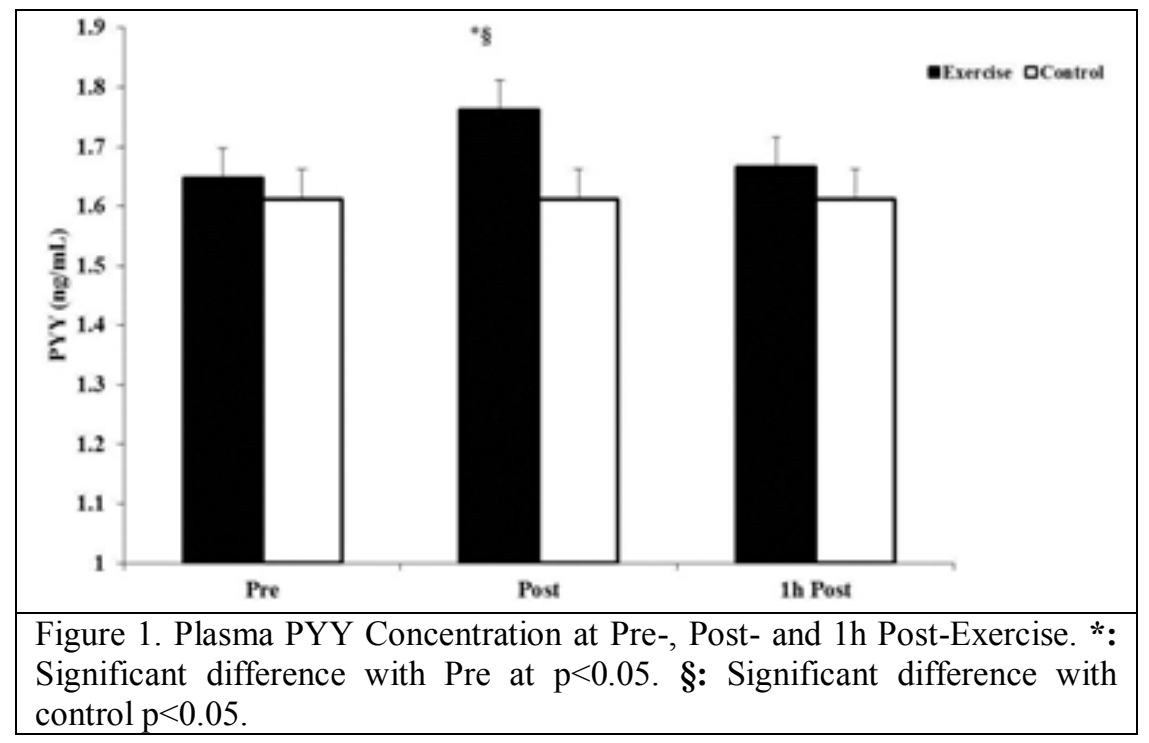

\section{DISCUSSION}

Appetite control plays a critical role in the competition between energy consumption and energy expenditure. Exercise-induced changes in appetite are of interest over the last decade. Recently, special attention has been paid to understand the central and peripheral mechanisms involved in the regulation of energy balance, especially in the appetite control (21). 

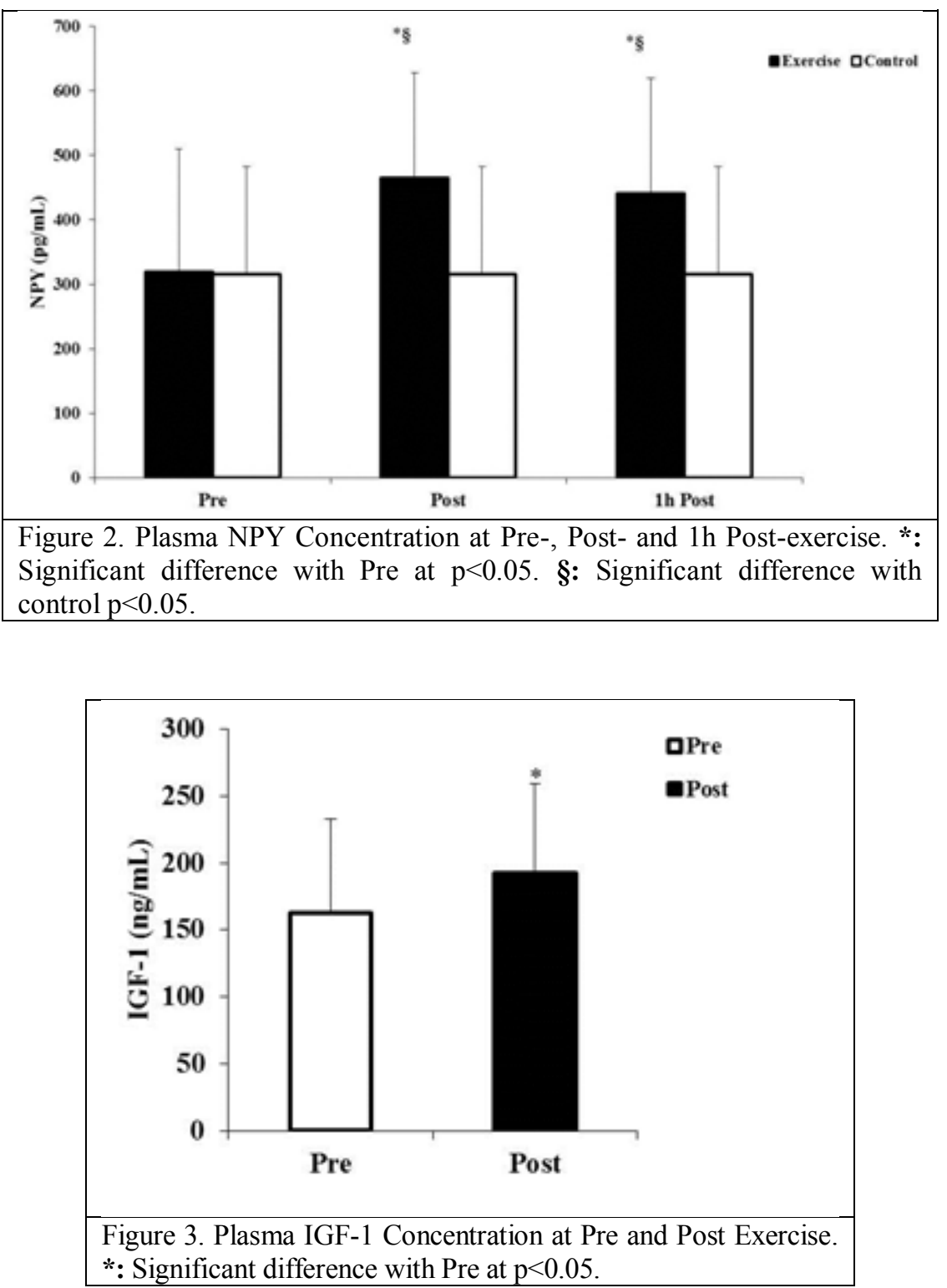

PYY and NPY have been reported to influence on appetite and can result in suppression and stimulation of food intake, respectively (9). As mentioned previously, PYY is secreted predominantly from L-cells of the distal gastrointestinal tract and exert its effect through the arcuate $\mathrm{Y}$ receptors resulting in inhibition of NPY neurons and food intake (23). The finding of this study revealed that a single exhausting exercise session increased plasma PYY concentration at post-exercise. These data are consistent with the finding of Mackelvie et al. (2007) reported significant increase in PYY levels following $60 \mathrm{~min}$ of cycling at $65 \%$ of maximal hart rate (MHR) (1h after standardized breakfast) in normal- and overweight male adolescents (17). In addition, Ueda et al. (2009) reported significant increase in plasma PYY levels after standardized breakfast followed by constant cycling exercise at $50 \%$ of $\mathrm{VO}_{2} \mathrm{max}$ in obese 
young males (4, 5). Also, Broom et al. (2009) investigated PYY response to an acute bout of aerobic exercise (60 min run at a speed $70 \%$ of $\mathrm{VO}_{2} \max$ on treadmill) (18). They observed significant elevation in postexercise plasma PYY concentration and appetite is suppressed during and for a short time after exercise in healthy males (18). Also, Ueda et al. (2013) observed significant increase in PYY level after 60 min of cycling at $65 \%$ of max heart rate (MHR) (1 h after breakfast) in middle-aged women subjects (15). In contrast to our finding, however, Larson-Meyer et al. (2012) were not able to show significant increase in PYY level after 60 min run or walk at $70 \%$ of $\mathrm{VO}_{2} \mathrm{max}$, in nine middle-aged women runners (16). This contrasting finding may be explained by the different in sex of the subjects examined. Larson-Meyer et al. (2012) used middle-aged women as subjects (16) whereas our subjects and/or published studies $(4,5,17,18)$ were males and some evidence showed that appetite hormones/metabolic responses may differ in females compared with males (2) although further research is required before conclusions can be drawn.

In this study, PYY returned to preexercise level following $1 \mathrm{~h}$ recovery. Similarly to this result, some of the previous studies reported that PYY levels remained elevated at least up to $1 \mathrm{~h}$ post exercise (3-5, 17). However, in contrast to our finding, previous study reported PYY level remained elevated up to 3 and $7 \mathrm{~h}$ after $50 \mathrm{~min}$ submaximal bout of exercise on the cycle ergometer at $60 \%$ of $\mathrm{VO}_{2} \max$ (14) and running on treadmill (4). Collectively, these findings suggest that acute exercise affect circulating PYY level which may regulate appetite following exercise.

The mechanisms underlying the changes in plasma PYY during exercise are unclear in detail. However, it is reported that IGF-1 stimulation expression and secretion of PYY in rodent (9). This increased IGF-1 at postexercise in experimental group [in this study consistently with previous investigations (24-26)], and it can explain that increased PYY concentration immediately after exhausting exercise may be related to IGF-1 signals which may influence appetite in young athletes.

Even though plasma NPY levels do not reflect NPY secretion in the brain, however, plasma NPY levels may originate from peripheral sympathetic nerve secretion or the adrenal gland and/ or adipose tissue during exercise in humans $(27,28)$. In addition our finding show that plasma NPY concentration increased significantly at post and $1 \mathrm{~h}$ post a single exhausting exercise session in young athletes. This finding is accordance with previous study that reported significant increase in plasma NPY after incremental cycle ergometer test to exhaustion in athletes (19). As mentioned earlier, NPY secreted into both circulating and paraventricular nucleus in hypothalamus (12). Circulating NPY does not penetrate the blood-brain barrier (29). Therefore, plasma NPY level may be unrelated to appetite regulation following strenuous exercise. Increased plasma NPY level after incremental cycle ergometer test to exhaustion may stimulate angiogenesis (30), regulate blood pressure and electrolyte homeostasis (31).

Our study has some limitations. We measured total PYY rather than $\mathrm{PYY}_{3-36}$, however, previous studies reported a high positive correlation between total PYY and $\mathrm{PYY}_{3-36}$ (32) and acute exercise-induced changes blood PYY3-36 levels is similar to the time course of changes in blood total PYY level (5). Furthermore, we did not assess hunger following our single exhausting bout of exercise or obtain food intake measurements into the recovery period which could have provided additional importance.

\section{CONCLUSION}

In conclusion our findings showed that plasma PYY concentration increased 
following a single exhausting exercise session in young athletes. The actions of this gut peptide is not yet completely understood but it seems that via central circulation, PYY cross the blood brain barrier and directly interact with the arcuate $\mathrm{Y}$ receptors resulting inhibition of NPY neurons and food intake. Therefore, increased plasma PYY concentration after a single exhausting exercise session in young athletes may possibly contribute to appetite suppression. However, increased plasma NPY after this type of exercise may not be related to appetite regulation because it does not cross the blood brain barrier, rather it may assumed to stimulate angiogenesis and show a vasoconstrictive and mitogenic effect on blood vessels $(12,32)$.

\section{ACKNOWLEDGMENTS}

This study was supported by the research grant from Islamic Azad University, Mariwan Branch to Mr Hassan Faraji. The authors express their thanks to all the volunteers for their participation in this study.

\section{REFFRENCES}

1. Jakicic JM, Clark K, Coleman E, Donnelly JE, Foreyt J, Melanson E, et al. American College of Sports Medicine position stand. Appropriate intervention strategies for weight loss and prevention of weight regain for adults. Medicine and science in sports and exercise. 2001;33(12):2145-56.

2. Stensel D. Exercise, appetite and appetite-regulating hormones: implications for food intake and weight control. Annals of nutrition \& metabolism. 2010;57 Suppl 2:36-42.

3. Martins C, Morgan LM, Bloom SR, Robertson MD. Effects of exercise on gut peptides, energy intake and appetite. The Journal of endocrinology. 2007;193(2):251-8.

4. Ueda SY, Yoshikawa T, Katsura Y, Usui T, Fujimoto S. Comparable effects of moderate intensity exercise on changes in anorectic gut hormone levels and energy intake to high intensity exercise. The Journal of endocrinology. 2009;203(3):357-64.

5. Ueda SY, Yoshikawa T, Katsura Y, Usui T, Nakao H, Fujimoto S. Changes in gut hormone levels and negative energy balance during aerobic exercise in obese young males. The Journal of endocrinology. 2009;201(1):151-9.

6. Broom DR, Stensel DJ, Bishop NC, Burns SF, Miyashita M. Exercise-induced suppression of acylated ghrelin in humans. Journal of applied physiology (Bethesda, Md : 1985). 2007;102(6):2165-71.

7. Routtenberg A, Kuznesof AW. Self-starvation of rats living in activity wheels on a restricted feeding schedule. Journal of comparative and physiological psychology. 1967;64(3):414-21.

8. Neary MT, Batterham RL. Peptide YY: food for thought. Physiology \& behavior. 2009;97(5):616-9.

9. Wynne K, Stanley S, McGowan B, Bloom S. Appetite control. Journal of Endocrinology. 2005;184(2):291-318.

10. Turtzo LC, Lane MD. NPY and neuron-adipocyte interactions in the regulation of metabolism. Exs. 2006(95):133-41

11.Zukowska-Grojec Z, Wahlestedt C. Origin and Actions of Neuropeptide Y in the Cardiovascular System. In: Colmers W, Wahlestedt C, editors. The Biology of Neuropeptide Y and Related Peptides. Contemporary Neuroscience: Humana Press; 1993. p. 315-88.

12. Kokot F, Ficek R. Effects of neuropeptide Y on appetite. Mineral and electrolyte metabolism. 1999;25(4-6):3035 .

13. Jones TE, Basilio JL, Brophy PM, McCammon MR, Hickner RC. Long-term exercise training in overweight adolescents improves plasma peptide YY and resistin. Obesity (Silver Spring, Md). 2009;17(6):1189-95.

14. Cheng MH, Bushnell D, Cannon DT, Kern M. Appetite regulation via exercise prior or subsequent to high-fat meal consumption. Appetite. 2009;52(1):193-8.

15. Ueda SY, Miyamoto T, Nakahara H, Shishido T, Usui T, Katsura Y, et al. Effects of exercise training on gut hormone levels after a single bout of exercise in middle-aged Japanese women. SpringerPlus. 2013;2(1):83.

16. Larson-Meyer DE, Palm S, Bansal A, Austin KJ, Hart AM, Alexander BM. Influence of Running and Walking on Hormonal Regulators of Appetite in Women. Journal of Obesity. 2012;2012:15.

17. Mackelvie KJ, Meneilly GS, Elahi D, Wong AC, Barr SI, Chanoine JP. Regulation of appetite in lean and obese adolescents after exercise: role of acylated and desacyl ghrelin. The Journal of clinical endocrinology and metabolism. 2007;92(2):648-54.

18. Broom DR, Batterham RL, King JA, Stensel DJ. Influence of resistance and aerobic exercise on hunger, circulating levels of acylated ghrelin, and peptide YY in healthy males2009 2009-01-01 00:00:00. R29-R35 p.

Faraji, H., Rahimi, R., Dabagh, S., Nikookheslat. (2014). Ann Appl Sport Sci, 2(3): 23-32. 
19. Smitka K, Papezova H, Vondra K, Hill M, Hainer V, Nedvidkova J. A higher response of plasma neuropeptide $\mathrm{Y}$, growth hormone, leptin levels and extracellular glycerol levels in subcutaneous abdominal adipose tissue to Acipimox during exercise in patients with bulimia nervosa: single-blind, randomized, microdialysis study. Nutrition \& metabolism. 2011;8(1):81.

20. Zajadacz B, Skarpańska-Stejnborn A, Brzenczek-Owczarzak W, Juszkiewicz A, Naczk M, Adach Z. The influence of physical exercise on alterations in concentrations of neuropeptide $\mathrm{Y}$, leptin and other selected hormonal and metabolic parameters in sportspeople. Biology of Sport. 2009;26(4):309-24.

21. Wang J, Chen C, Wang RY. Influence of short- and long-term treadmill exercises on levels of ghrelin, obestatin and NPY in plasma and brain extraction of obese rats. Endocrine. 2008;33(1):77-83.

22. Dill DB, Costill DL. Calculation of percentage changes in volumes of blood, plasma, and red cells in dehydration. Journal of applied physiology. 1974;37(2):247-8.

23. Gueugnon C, Mougin F, Nguyen NU, Bouhaddi M, Nicolet-Guenat M, Dumoulin G. Ghrelin and PYY levels in adolescents with severe obesity: effects of weight loss induced by long-term exercise training and modified food habits. European journal of applied physiology. 2012;112(5):1797-805.

24. Batterham RL, Cowley MA, Small CJ, Herzog H, Cohen MA, Dakin CL, et al. Gut hormone PYY3-36 physiologically inhibits food intake. Nature. 2002;418(6898):650-4.

25. Bermon S, Ferrari P, Bernard P, Altare S, Dolisi C. Responses of total and free insulin-like growth factor-I and insulin-like growth factor binding protein-3 after resistance exercise and training in elderly subjects. Acta physiologica Scandinavica. 1999;165(1):51-6.

26. Boroujerdi S, Rahimi R. The apoptotic response to resistance exercise with different intensities in athletes. Med Sport. 2011;64(1):31-44.

27. Coiro V, Casti A, Volta E, Melani A, Rubino P, Saccani-Jotti G, et al. Effect of physical training on reduction of circulating neuropeptide $Y$ levels in elderly humans. Journal of endocrinological investigation. 2010;33(2):132-3.

28. Rahimi R, Ghaderi M, Mirzaei B, Faraji H. Acute IGF-1, cortisol and creatine kinase responses to very short rest intervals between sets during resistance exercise to failure in men. World Appl Sci J. 2010;8:1287-93.

29. Zukowska-Grojec Z. Neuropeptide Y. A novel sympathetic stress hormone and more. Annals of the New York Academy of Sciences. 1995;771:219-33.

30. Zukowska-Grojec Z. Neuropeptide Y: Implication in vascular remodeling and novel therapeutics. Drug News and Perspectives. 1997;10:587-95.

31. Playford RJ, Cox HM. Peptide YY and neuropeptide Y: two peptides intimately involved in electrolyte homeostasis. Trends in pharmacological sciences. 1996;17(12):436-8.

32. Tsilchorozidou T, Batterham RL, Conway GS. Metformin increases fasting plasma peptide tyrosine tyrosine (PYY) in women with polycystic ovarian syndrome (PCOS). Clinical endocrinology. 2008;69(6):936-42. 
تازههاى علوم كاربردى ورزش

\section{اثر حاد فعاليت ورزشى فزآينده بر غلظت يِيتيد نوروييتيد Y و IGF-1 يلاسما در ورزشكاران جوان 'حسن فرجى *، 'رحمان رحيمى، "سعيد دباغ نيكوخصلت}

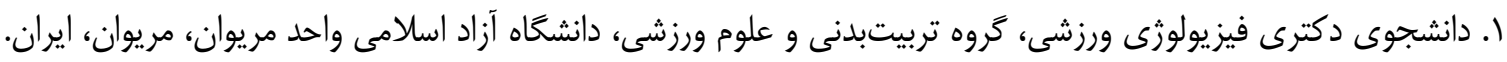

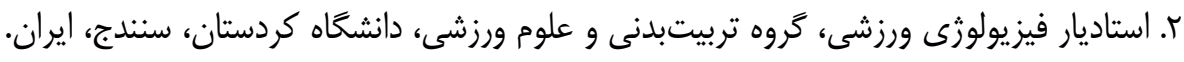

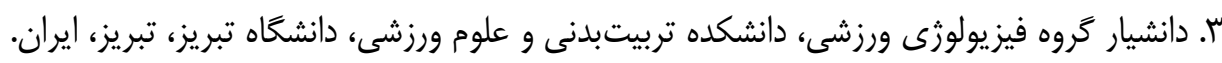

جكيده

مشخص شده است كه فعاليت ورزشى يك استراتزى جهت مقابله با هاقى محسوب مىشود. اين كار توسط ايجاد تعادل انرزى منفى به وسيله

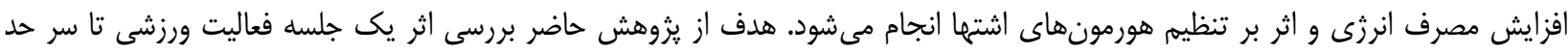

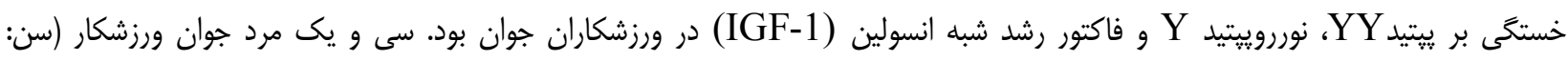
آز

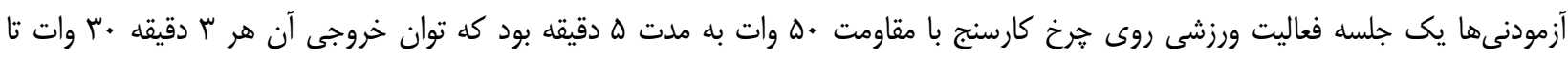

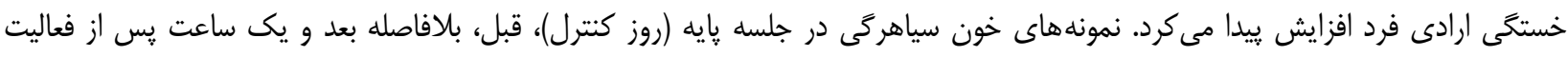

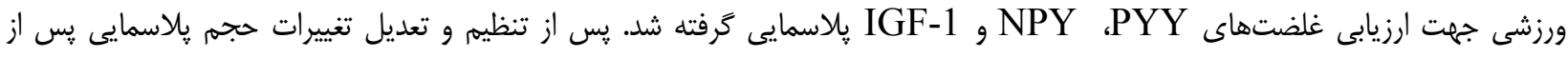

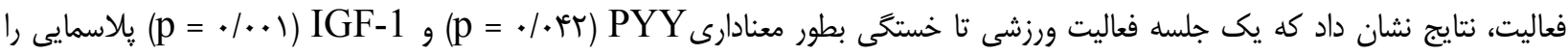

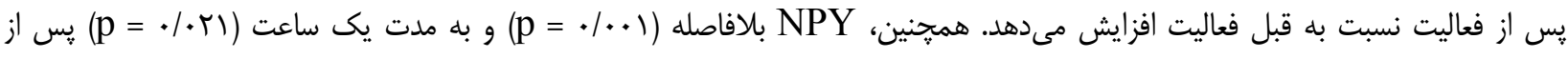

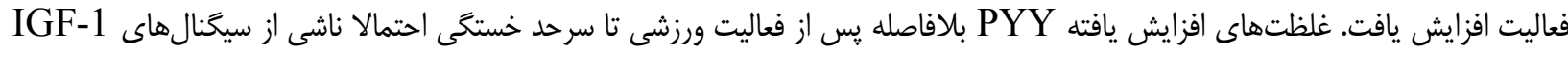

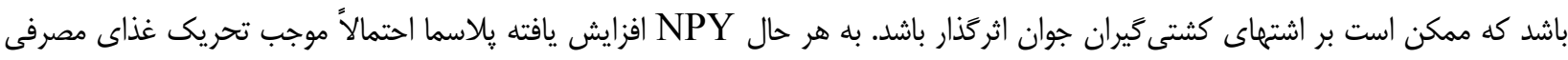
نيست جون نمى تواند ازديواره مغزى -خونى عبور كند. وازًان كليدى: اشتها، غذاى مصرفى، ورزشكاران، بى اشتهايى. 
